\title{
Predominance of Trichoderma and Penicillium in cellulolytic aerobic filamentous fungi from subtropical and tropical forests in China, and their use in finding highly efficient $\beta$-glucosidase
}

\author{
Zheng Zhang ${ }^{\dagger}$, Jun-Liang Liư ${ }^{\dagger}$ Jian-Yi Lan ${ }^{\dagger}$, Cheng-Jie Duan, Qing-Sheng Ma and Jia-Xun Feng ${ }^{*}$
}

\begin{abstract}
Background: Cellulose is the most abundant biomass on earth. The major players in cellulose degradation in nature are cellulases produced by microorganisms. Aerobic filamentous fungi are the main sources of commercial cellulase. Trichoderma reesei has been explored extensively for cellulase production; however, its major limitations are its low $\beta$-glucosidase activity and inefficiency in biomass degradation. The aim of this work was to isolate new fungal strains from subtropical and tropical forests in China, which produce high levels of cellulase in order to facilitate development of improved commercial cellulases.
\end{abstract}

Results: We isolated 305 fungal strains from 330 samples collected from subtropical and tropical virgin forests in China. Of these, 31 strains were found to have Avicelase activity of more than $0.2 \mathrm{U} / \mathrm{ml}$ in liquid batch cultivation. Molecular analyses of the 31 strains based on internal transcribed spacer sequences revealed that 18 were Trichoderma and 13 were Penicillium species. The best-performing isolate was Trichoderma koningiopsis FCD3-1, which had similar Avicelase activity to T. reesei Rut-C30. Most interestingly, strain FCD3-1 exhibited extracellular $\beta$-glucosidase activity of $1.18 \mathrm{U} / \mathrm{ml}$, which was approximately 17 times higher than that of Rut-C30. One $\beta$-glucosidase secreted by FCD3-1 was purified, and its gene was cloned and identified. The $\beta$-glucosidase belonged to glycosyl hydrolase $(\mathrm{GH})$ family 3 , sharing the highest identity of $94 \%$ with a GH family 3 protein from Trichoderma atroviride IMI 206040, and was designated TkBgl3A. The optimal pH and temperature of TkBgl3A were 4.5 and $65^{\circ} \mathrm{C}$, respectively. The enzyme retained over $90 \%$ activity for 360 hours at $\mathrm{pH} 4.0$ and $30^{\circ} \mathrm{C}$, which are the usual conditions used for simultaneous saccharification and fermentation (SSF) of cellulose to ethanol. The enzyme showed significantly higher specific activity toward natural substrate cellobiose $(141.4 \mathrm{U} / \mathrm{mg})$ than toward artificial substrate p-nitrophenyl-beta-D-glucopyranoside (108.0 U/mg).

Conclusions: Strains of Trichoderma and Penicillium were the predominant cellulolytic fungi in subtropical and tropical forests in China. T. koningiopsis FCD3-1 was the most efficient producer of cellulase, and also produced a high level of $\beta$-glucosidase. The high specific activity toward cellobiose and stability under SSF conditions of the purified $\beta$-glucosidase from FCD3-1 indicates its potential application in SSF of cellulose to bioethanol.

Keywords: Trichoderma, Penicillium, Cellulase, $\beta$-glucosidase

\footnotetext{
* Correspondence: jiaxunfeng@sohu.com

${ }^{\dagger}$ Equal contributors

State Key Laboratory for Conservation and Utilization of Subtropical

Agro-bioresources, Guangxi Key Laboratory of Subtropical Bioresources

Conservation and Utilization, Key Laboratory of Ministry of Education for

Microbial and Plant Genetic Engineering, College of Life Science and

Technology, Guangxi University, 100 Daxue Road, Nanning, Guangxi 530004,

People's Republic of China
} 


\section{Background}

Cellulose, a type of homogeneous polysaccharide that exists as units of cellobiose connected by $\beta-1,4$-glycosidic bonds, is the most abundant renewable biomass in nature, with $7.2 \times 10^{10}$ tons synthesized by photosynthesis every year [1]. Cellulose can be hydrolyzed by cellulase into D-glucose, which can be further transformed into renewable fuel and various valuable chemicals [2]. These characteristics have stimulated studies on the degradation and utilization of cellulose. However, natural cellulose is difficult to be degraded to glucose owing to its structure and the fact that it is often found in combination with lignin and hemicellulose [3]. Cellulose degradation and utilization are part of the global carbon cycle, with the major degradation power of cellulose in nature derived from cellulases produced by microorganisms [4-7].

Hydrolysis of cellulose to glucose requires three groups of enzymes: endo-1,4- $\beta$-glucanase (EC 3.2.1.4), cellobiohydrolase (EC 3.2.1.91), and $\beta$-glucosidase (EC 3.2.1.21). Endo-1,4- $\beta$-glucanase randomly cuts cellulose chains, yielding cellulose ends, while cellobiohydrolase attacks the cellulose chains from the reducing or non-reducing ends, yielding cellobiose, and $\beta$-glucosidase hydrolyzes cellobiose and cello-oligosaccharides to form glucose [8].

The mechanisms of microorganisms producing cellulases are very diverse. Among these microorganisms are the aerobic filamentous fungi, which produce an extracellular non-composite cellulase system $[2,4]$. They are the main sources of commercial cellulase, with Trichoderma reesei being the most widely used [9].

In the 1970s, Mandels and Sternberge assessed the cellulase production of over 14,000 collected strains, and found that $T$. reesei produced the highest cellulase activity. Various $T$. reesei strains with higher yields of cellulase were then developed by mutagenesis. Of these, $T$. reese $i$ Rut-C30 was one of the most characteristic strains with effective cellulase yield, and has been selected as the reference strain for many studies [10].

However, the hyperproducing mutant strains of T. reesei produce cellulase with all essential components, but lack the optimum amount of $\beta$-glucosidase for efficient cellulose hydrolysis, and the $\beta$-glucosidase it produces is also glucose-sensitive [11]. As $\beta$-glucosidase catalyzes the final step of cellulose hydrolysis thus releasing glucose from the inhibitory cellobiose, it plays an important role in the biological conversion of cellulose to glucose [12].

Based on sequence similarities, $\beta$-glucosidases are mostly placed in either family 1 or family 3 of GH [13]. Product inhibition and thermal inactivation of $\beta$-glucosidases constitute two major barriers to commercial development of enzymatic hydrolysis of cellulose [14]. Therefore, the production costs of cellulosic ethanol would be significantly reduced by improving the glucose tolerance and thermostablity of $\beta$-glucosidases [15]. In addition, $\beta$-glucosidase activities are generally measured using artificial substrates such as $p$-nitrophenyl- $\beta$-D-glycopyranoside (pNPG) or 4methylumbelliferyl- $\beta$-D-glucuronide. When using these artificial substrates, most enzymes show higher catalytic activity toward artificial substrates than toward cellobiose [16-20]. However, UeBgl3A from Ustilago esculenta and a recombinant $\beta$-glucosidase from Caldicellulosiruptor saccharolyticus are exceptions, with higher catalytic activity toward cellobiose than toward artificial substrate [21,22].

Guangxi and Yunnan Provinces are in southwest China, with the Tropic of Cancer passing through them. There is abundant sunlight, bountiful rainfall, and large areas of subtropical and tropical forests. These forests are well preserved because of low levels of human activity, and soils are mainly weakly acidic. These conditions provide abundant biomass and microbial resources. Different climatic types and natural vegetation characteristics have led to the evolution of diverse cellulolytic organisms capable of degrading cellulose [23].

In this work, novel fungal strains producing high cellulase activity were isolated, screened, and identified from soil samples systematically collected from virgin forests in subtropical and tropical climates in Guangxi and Yunnan Provinces in China, with a predominance of Trichoderma and Penicillium. Trichoderma koningiopsis FCD3-1 was the most efficient producer of cellulases, and also had extracellular $\beta$-glucosidase activity at levels approximately 17 times higher than that of T. reesei Rut-C30. One $\beta$ glucosidase purified from FCD3-1 was stable under the usual conditions of simultaneous saccharification and fermentation (SSF), and showed high activity toward the natural substrate cellobiose, indicating its potential application for saccharification of cellulosic biomass for bioethanol production.

\section{Results}

Isolation, screening, and identification of fungal strains with higher cellulase activity from forests in subtropical and tropical regions of China

In total, 330 soil and rotten wood samples were collected from sampling sites in virgin forests in 8 natural reserves in Guangxi and Yunnan Provinces, China (Table 1). From these 330 samples, 305 fungal strains were isolated, using agar medium plates containing Whatman No. 1 filter paper as the sole carbon source. Of the 305 fungal strains, 231 could be cultured by shake-flask cultivation, using liquid medium containing microcrystalline cellulose (Avicel PH101) as the sole carbon source. Of these 231 fungal strains (Table 2), 51 produced Avicelase activity of greater than $0.05 \mathrm{U} / \mathrm{ml} 3$ days after cultivation under these conditions (Table 2).

The optimum $\mathrm{pH}$ and temperature (Table 3) of the cellulases produced by the 51 fungal strains were measured against Avicel. Following this, the Avicelase activity of 
Table 1 Samples collected from forests of national natural reserves in subtropical and tropical regions of China

\begin{tabular}{|c|c|c|c|c|c|}
\hline Sample location & Date of sampling & $\begin{array}{l}\text { Latitude and longitude of } \\
\text { one sampling point }\end{array}$ & Altitude, $\mathrm{m}$ & Temperature, ${ }^{\circ} \mathrm{C}$ & Samples, $\mathbf{n}$ \\
\hline Shankou Mangrove National Natural Reserve & Sep 10, 2007 & $\mathrm{~N} 21^{\circ} 34^{\prime} 31.1^{\prime \prime} \mathrm{E} 109^{\circ} 41^{\prime} 06.1^{\prime \prime}$ & 0 & 30 to 34 & 31 \\
\hline Xishuangbanna National Natural Reserve & Aug 23, 2008 & $\mathrm{~N} 21^{\circ} 36^{\prime} 06.3^{\prime \prime} \mathrm{E} 101^{\circ} 35^{\prime} 09.1^{\prime \prime}$ & 300 to 500 & 28 to 34 & 56 \\
\hline Golden Camellia National Natural Reserve & Oct 15,2007 & $\mathrm{~N} 21^{\circ} 44^{\prime} 52.1^{\prime \prime} \mathrm{E} 108^{\circ} 06^{\prime} 50.7^{\prime \prime}$ & 50 to 200 & 24 to 28 & 62 \\
\hline Shiwandashan National Natural Reserve & July 20, 2007 & 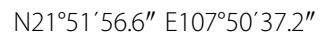 & 300 to 600 & 26 to 30 & 26 \\
\hline Longgang National Natural Reserve & July 18, 2007 & $\mathrm{~N} 22^{\circ} 28^{\prime} 18.1^{\prime \prime} \mathrm{E} 106^{\circ} 57^{\prime} 26.4^{\prime \prime}$ & 200 to 300 & 28 to 32 & 19 \\
\hline Dawangling National Natural Reserve & July 13, 2007 & $\mathrm{~N} 23^{\circ} 49^{\prime} 23.4^{\prime \prime} \mathrm{E} 106^{\circ} 28^{\prime} 01.5^{\prime \prime}$ & 200 to 400 & 26 to 30 & 37 \\
\hline Huaping National Natural Reserve & Oct 30, 2008 & 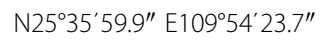 & 800 to 1000 & 24 to 28 & 37 \\
\hline Baimaxueshan National Natural Reserve & Aug 27, 2008 & $\mathrm{~N} 28^{\circ} 14^{\prime} 23.7^{\prime \prime}$ E99 $18^{\prime} 02.6^{\prime \prime}$ & 3600 to 3900 & 20 to 26 & 62 \\
\hline
\end{tabular}

cellulases produced by the 51 strains at peak enzyme production was measured under conditions of the respective optimum $\mathrm{pH}$ and temperature of the crude enzyme. Of the 51 strains, 31 produced Avicelase activity of greater than $0.2 \mathrm{U} / \mathrm{ml}$ (Tables 2 and 3), compared with $0.39 \mathrm{U} / \mathrm{ml}$ for $T$. reesei Rut-C30 under the same cultivation conditions. Two fungal strains, FCD3-1 and BM48-3, had Avicelase activity of 0.37 and $0.36 \mathrm{U} / \mathrm{ml}$, respectively, which did not differ statistically from that of Rut-C30. Strains HP35-3 and HP29-3 also produced relatively high Avicelase activity at 0.34 and $0.33 \mathrm{U} / \mathrm{ml}$, respectively.

The 31 strains were further identified by sequence analysis of internal transcribed spacer (ITS) and observation of morphological characteristics. Thus, 18 strains were identified as belonging to genus Trichoderma and 13 to Penicillium (Table 3).

Notably, 9 of the 31 strains were isolated from Huaping National Nature Reserve in Guangxi, which was the sample location that gave the highest number of strains with Avicelase activity of greater than $0.2 \mathrm{U} / \mathrm{ml}$, and 5 of these 9 strains were identified as Trichoderma harzianum
(Table 3). Of the 31 strains, 8 were isolated from Xishuangbanna National Nature Reserve in Yunnan, which was the sample location with the second highest number of strains producing Avicelase activity greater than $0.2 \mathrm{U} / \mathrm{ml}$, and 3 of these 8 strains were identified as T. harzianum (Table 3).

\section{Enzymatic characterization of cellulases from fungal strains producing higher Avicelase activity}

The cellulase produced by the four highest-producing strains, FCD3-1, BM48-3, HP35-3, and HP29-3, were further measured against substrates of filter paper, carboxylmethylcellulose sodium salt (CMC-Na), and pNPG, in addition to Avicel. Of the four strains tested, T. koningiopsis strain FCD3-1 had the most efficient enzyme activity toward Avicel, filter paper, and CMC-Na (Figure 1). Interestingly, strain FCD3-1 produced a high level of $\beta$-glucosidase activity at $1.18 \mathrm{U} / \mathrm{ml}$, which was approximately 17 times higher than that of Rut-C30 (Figure 1).

The ITS of strain FCD3-1 was amplified by PCR and sequenced (GenBank accession number KJ619600). Using

Table 2 Isolation and screening of fungal strains producing Avicelase activity from forests of national natural reserves in subtropical and tropical regions of China

\begin{tabular}{|c|c|c|c|c|c|}
\hline \multirow[t]{3}{*}{ Sample location } & \multirow[t]{3}{*}{ Samples, $\mathbf{n}$} & \multicolumn{4}{|c|}{ Strains isolated, $\mathbf{n}$} \\
\hline & & \multicolumn{2}{|c|}{ Culture method } & \multicolumn{2}{|c|}{ Avicelase activity } \\
\hline & & Filter paper & Avicel & $>0.05 \mathrm{U} / \mathrm{ml}^{\mathrm{a}}$ & $>0.2 \mathrm{U} / \mathrm{ml}^{\mathrm{b}}$ \\
\hline Shankou Mangrove National Natural Reserve & 31 & 20 & 5 & 2 & 2 \\
\hline Xishuangbanna National Natural Reserve & 56 & 63 & 63 & 15 & 8 \\
\hline Golden Camellia National Natural Reserve & 62 & 64 & 51 & 8 & 3 \\
\hline Shiwandashan National Natural Reserve & 26 & 25 & 15 & 3 & 3 \\
\hline Longgang National Natural Reserve & 19 & 14 & 14 & 1 & 1 \\
\hline Dawangling Natural Reserve & 37 & 20 & 10 & 1 & 0 \\
\hline Huaping National Natural Reserve & 37 & 53 & 53 & 16 & 9 \\
\hline Baimaxueshan National Natural Reserve & 62 & 46 & 20 & 5 & 5 \\
\hline Total & 330 & 305 & 231 & 51 & 31 \\
\hline
\end{tabular}

Indicates that Avicelase activity was measured under conditions of $\mathrm{pH} 5.0$ and $50^{\circ} \mathrm{C} 5$ days after cultivation of fungal strains in liquid culture.

${ }^{b}$ Indicates that Avicelase activity was measured under optimum $\mathrm{pH}$ and temperature of the crude enzyme produced by each fungal strain in liquid culture at peak enzyme production. 
Table $\mathbf{3}$ The hydrolytic performance of the culture supernatants from the $\mathbf{3 1}$ fungal strains against Avicel

\begin{tabular}{|c|c|c|c|c|c|c|c|c|}
\hline \multirow[t]{2}{*}{ Strains } & \multirow[t]{2}{*}{ Source/reference } & \multicolumn{2}{|l|}{ Closest match of ITS in GenBank } & \multirow{2}{*}{$\begin{array}{l}\text { Species } \\
\text { identification }\end{array}$} & \multirow{2}{*}{$\begin{array}{l}\text { ITS GenBank } \\
\text { accession number }\end{array}$} & \multirow{2}{*}{$\begin{array}{l}\text { Optimal } \\
\text { pH of } \\
\text { Avicelase }\end{array}$} & \multirow{2}{*}{$\begin{array}{l}\text { Optimal } \\
\text { temperature } \\
\text { of Avicelase, }{ }^{\circ} \mathrm{C}\end{array}$} & \multirow{2}{*}{$\begin{array}{l}\text { Avicelase } \\
\text { activity, } \\
\mathrm{U} / \mathrm{ml}^{\mathrm{a}}\end{array}$} \\
\hline & & Closest strain (accession number) & Maximum identity & & & & & \\
\hline Rut-C30 & [24] & Trichoderma reesei strain ATCC 56765 (Rut-C30) (X93938.1) & $100 \%$ & T. reesei & - & 4.0 to 5.0 & 55 & $0.39 \pm 0.004$ \\
\hline FCD 3-1 & Golden Camellia NNR & Trichoderma koningiopsis strain T-1 (KC884758.1) & $100 \%$ & T. koningiopsis & KJ619600 & 4.0 to 5.0 & 55 & $0.37 \pm 0.007$ \\
\hline BM 48-3 & Baimaxueshan NNR & Hypocrea cremea strain GJS 91-125 (AY737760.1) & $99.2 \%$ & H. cremea & KJ619591 & 4.0 to 4.5 & 50 & $0.36 \pm 0.006$ \\
\hline HP 35-3 & Huaping NNR & Trichoderma atroviride voucher TriAtv_JSB791 (KC569351.1) & $100 \%$ & T. atroviride & KJ619607 & 4.0 to 5.0 & 55 & $0.34 \pm 0.006$ \\
\hline HP 29-3 & Huaping NNR & Trichoderma harzianum RP1-4 (JX493008.1) & $100 \%$ & T. harzianum & KJ619604 & 5.0 & 55 & $0.33 \pm 0.012$ \\
\hline HP37-2 & Huaping NNR & Trichoderma harzianum voucher TriH_JSB301 (KC569359.1) & $100 \%$ & T. harzianum & KJ619608 & - & - & $0.33 \pm 0.030$ \\
\hline BM16-3 & Baimaxueshan NNR & Penicillium oxalicum strain a1s2_d38 (KC344971.1) & $100 \%$ & P. oxalicum & KJ619590 & 4.5 to 5.0 & 50 & $0.32 \pm 0.014$ \\
\hline ML5-2a & Xishuangbanna NNR & Trichoderma sp. FKI-6626 (AB733349.1) & $97 \%$ & Trichoderma sp. & KJ619623 & 4.5 & 55 & $0.32 \pm 0.003$ \\
\hline ML29-3 & Xishuangbanna NNR & Trichoderma sp. SQR037 (GQ497168.1) & $100 \%$ & Trichoderma sp. & KJ619624 & 5.0 & 55 & $0.31 \pm 0.009$ \\
\hline HP33-1 & Huaping NNR & Trichoderma tawa strain LIPIMC0569 (KC847183.1) & $100 \%$ & T. tawa & KJ619605 & - & - & $0.30 \pm 0.011$ \\
\hline SK9-1 & Shankou mangrove NNR & Penicillium sp. 3 BRO-2013 (KF367495.1) & $100 \%$ & Penicillium sp. & KJ619620 & 4.5 & 45 & $0.30 \pm 0.004$ \\
\hline HP21-3 & Huaping NNR & Trichoderma harzianum voucher TriH_JSB301 (KC569359.1) & $100 \%$ & T. harzianum & KJ619603 & - & - & $0.30 \pm 0.004$ \\
\hline HP37-4 & Huaping NNR & Trichoderma piluliferum isolate wxm149 (HM061325.1) & $100 \%$ & T. piluliferum & KJ619609 & 4.5 & 55 & $0.29 \pm 0.011$ \\
\hline HP7-2 & Huaping NNR & Trichoderma harzianum Ir.112C (AY154949.1) & $100 \%$ & T. harzianum & KJ619602 & - & - & $0.29 \pm 0.007$ \\
\hline ML14-1 & Xishuangbanna NNR & Trichoderma harzianum strain LIPIMC0572 (KC847182.1) & $100 \%$ & T. harzianum & KJ619614 & 4.0 & 55 & $0.29 \pm 0.005$ \\
\hline ML12-1 & Xishuangbanna NNR & Trichoderma harzianum voucher TriH JSB301 (KC569359.1) & $99.7 \%$ & T.harzianum & KJ619613 & 4.0 to 5.0 & 55 & $0.29 \pm 0.003$ \\
\hline BM12-1 & Baimaxueshan NNR & Penicillium sp. 0312 F1 (EU926977.1) & $100 \%$ & Penicillium sp. & KJ619589 & 5.0 & 50 & $0.28 \pm 0.014$ \\
\hline HP35-1 & Huaping NNR & Trichoderma harzianum strain IPBCC07_547 (KC8471910.1) & $100 \%$ & T. harzianum & KJ619606 & 4.0 to 5.0 & 55 & $0.27 \pm 0.012$ \\
\hline ML16-1 & Xishuangbanna NNR & Trichoderma harzianum voucher TriH_JSB301 (KC569359.1) & $100 \%$ & T. harzianum & KJ619615 & 5.0 & 55 & $0.26 \pm 0.009$ \\
\hline ML4-2 & Xishuangbanna NNR & Trichoderma hamatum strain T-17 (FR87274.1) & $100 \%$ & T. hamatum & KJ619610 & 4.5 & 55 & $0.26 \pm 0.006$ \\
\hline S17-1 & Shiwandashan NNR & Penicillium aculeatum isolate A11 (EU781668.1) & $100 \%$ & P. aculeatum & KJ619618 & 5.0 & 60 & $0.25 \pm 0.003$ \\
\hline SK22-2 & Shankou mangrove NNR & Penicillium sp. 3 BRO-2013 (KF367495.1) & $100 \%$ & Penicillium sp. & KJ619621 & 3.5 to 5.0 & 40 to 45 & $0.24 \pm 0.021$ \\
\hline ML5-2 & Xishuangbanna NNR & Penicillium sp. 3 BRO-2013 (KF367495.1) & $100 \%$ & Penicillium sp. & KJ619611 & 4.5 to 5.0 & 55 to 60 & $0.24 \pm 0.016$ \\
\hline S17-2 & Shiwandashan NNR & Penicillium aculeatum strain LP67 (HQ392497.1) & $100 \%$ & P. aculeatum & KJ619619 & 4.0 to 5.0 & 55 to 60 & $0.24 \pm 0.008$ \\
\hline SY20-5 & Golden Camellia NNR & Penicillium oxalicum isolate C1-5 (KF986426.1) & $100 \%$ & P. oxalicum & KJ619622 & 4.5 to 5.0 & 50 to 55 & $0.24 \pm 0.004$ \\
\hline NG9 & Longgang NNR & Penicillium sp. 3 BRO-2013 (KF367495.1) & $100 \%$ & Penicillium sp. & KJ619616 & 4.0 to 4.5 & 50 & $0.23 \pm 0.009$ \\
\hline FC3-3 & Golden Camellia NNR & Penicillium sp. ZH7-E1 (FJ037747.1) & $100 \%$ & Penicillium sp. & KJ619599 & 4.0 to 5.0 & 55 & $0.22 \pm 0.016$ \\
\hline S15-3 & Shiwandashan NNR & Penicillium sp. 3 BRO-2013 (KF367495.1) & $100 \%$ & Penicillium sp. & KJ619617 & 5.0 & 55 & $0.21 \pm 0.022$ \\
\hline HP7-1 & Huaping NNR & Penicillium sp. 3 BRO-2013 (KF367495.1) & $100 \%$ & Penicillium sp. & KJ619601 & 5.0 & 55 & $0.21 \pm 0.015$ \\
\hline
\end{tabular}


Table 3 The hydrolytic performance of the culture supernatants from the $\mathbf{3 1}$ fungal strains against Avicel (Continued)

\begin{tabular}{|c|c|c|c|c|c|c|c|c|}
\hline BM58-1 & Baimaxueshan NNR & Trichoderma viride strain NEFU26 (KF944470.1) & $100 \%$ & T. viride & KJ619592 & - & - & $0.21 \pm 0.008$ \\
\hline ML11-1 & Xishuangbanna NNR & Penicillium oxalicum strain HL6 (KF746061.1) & $100 \%$ & P. oxalicum & KJ619612 & 5.0 & 55 & $0.21 \pm 0.004$ \\
\hline BM58-4 & Baimaxueshan NNR & Trichoderma viride isolate OTU220 (GU934567.1) & $100 \%$ & T. viride & KJ619593 & - & - & $0.20 \pm 0.003$ \\
\hline
\end{tabular}

ITS, internal transcribed spacer; NNR, National Natural Reserve.

andicates that Avicelase activity was measured under optimum pH and temperature of the crude enzyme produced by the strain in liquid culture at peak enzyme production. Avicelase activity produced by strains whose optimum $\mathrm{pH}$ and temperature for the crude enzyme were not tested was measured under conditions of $\mathrm{pH} 4.5$ and $55^{\circ} \mathrm{C} 5$ days after cultivation of fungal strains in liquid culture. Data are means \pm standard deviation from three replicates. The experiments were repeated three times and similar results were obtained. 


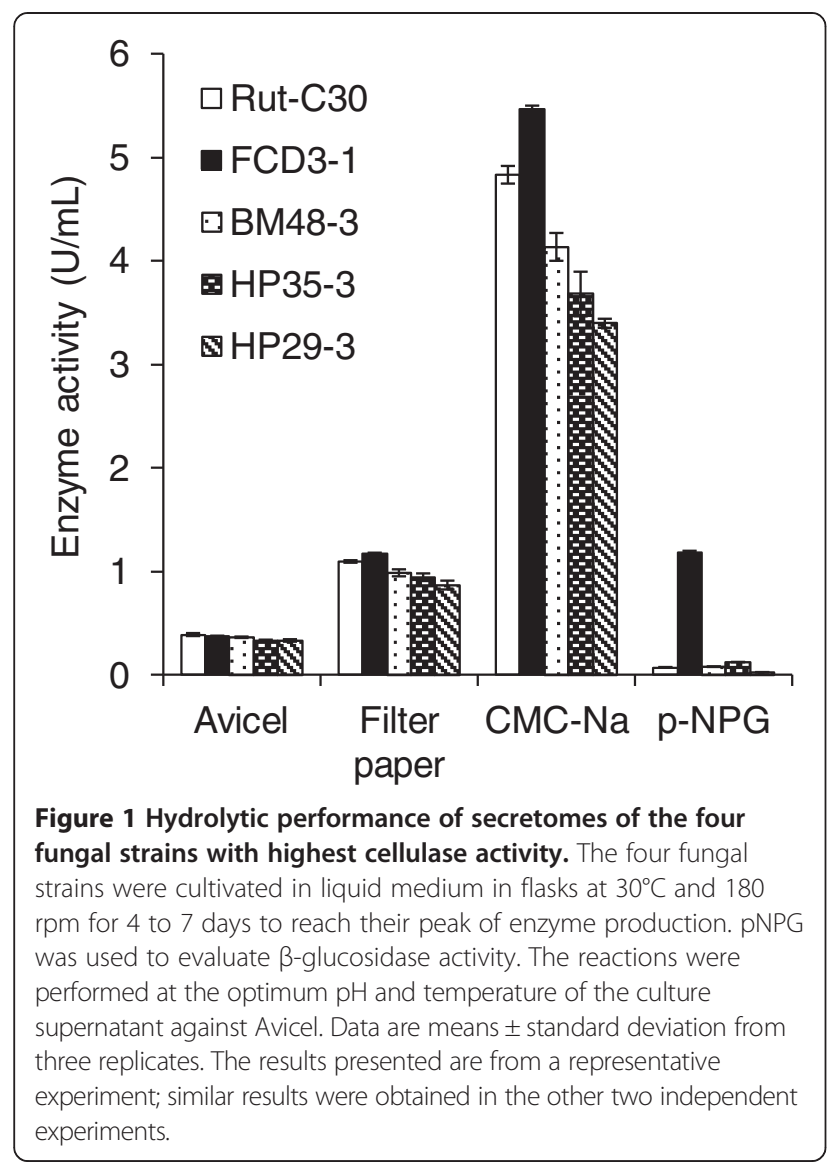

the BLAST algorithm, the ITS sequence of FCD3-1 was compared with sequences in the GenBank database, and the best BLAST match was found to be the ITS of $T$. koningiopsis strain T-1 (GenBank accession number KC884758) at $100 \%$ identity. The morphological identification of FCD3-1 (see Additional file 1) and the molecular identification of the strain were consistent. Therefore, fungal strain FCD3-1 was identified as $T$. koningiopsis.

Glucose was the sole hydrolytic product of Avicel hydrolyzed by the crude cellulase produced by strain FCD3-1 (Figure 2). In comparison, glucose and cellobiose were the major hydrolytic products of Avicel hydrolyzed by the crude cellulases produced by the fungal strains BM48-3, HP35-3, and HP29-3, and the reference strain Rut-C30 (Figure 2; see Additional file 2).

\section{Purification and characterization of one $\beta$-glucosidase secreted by $T$. koningiopsis FCD3-1}

To determine the $\beta$-glucosidase responsible for the high level of $\beta$-glucosidase activity by $T$. koningiopsis FCD3-1, the extracellular proteins secreted by this strain were subjected to protein purification. One $\beta$-glucosidase secreted by FCD3-1 was purified by using ammonium sulfate precipitation, followed by hydrophobic interaction chromatography and ion exchange chromatography. The homogeneity of the purified enzyme was confirmed by non-denaturing polyacrylamide gel electrophoresis (PAGE) analysis, which showed a single protein band after staining with Coomassie blue (Figure 3A), coincident with a $\beta$-glucosidase activity band detected using esculin as the substrate (Figure 3A). A single protein band was also detected after electrophoresis under denaturing conditions (SDS-PAGE), with molecular mass of about $100 \mathrm{kDa}$ (Figure 3A).

The 100-kDa band on SDS-PAGE was excised, subjected to trypsin digestion, and analyzed by liquid chromatography-tandem mass spectrometry (LC/MS/ MS). Mascot (A software from Matrix Science, London, UK) search showed that eight sequences in a GH family 3 protein (GenBank accession number EHK21862) from Trichoderma virens Gv29-8 matched (Table 4). The gene encoding the $\beta$-glucosidase was amplified from the genomic DNA of strain FCD3-1 and sequenced. This gene, with four introns, encoded a polypeptide with 866 amino acids, which contained the eight matched peptide sequences in the GH family 3 protein from $T$. virens Gv29-8, confirming that the cloned gene encoded the purified $\beta$-glucosidase.

The encoded polypeptide by the cloned gene shared its highest identity (94\%) with a GH3 protein (GenBank accession number EHK46786) from Trichoderma atroviride IMI 206040. Simple Modular Architecture Research Tool (SMART) analysis showed that the polypeptide composed of 4 domains (aa residues of 1 to 21 belonged to the signal peptide, aa 88 to 313 belonged to the GH3 Nterminal domain, aa 413 to 652 belonged to the GH3 C-terminal domain, and aa 788 to 856 was described as a fibronectin type III-like domain), indicating that the polypeptide was a GH3 $\beta$-glucosidase. Thus, the enzyme was named TkBgl3A.

\section{Characteristics of $\beta$-glucosidase TkBgl3A from T. koningiopsis FCD3-1}

The purified $\beta$-glucosidase TkBgl3A was most active toward pNPG at pH 4.5 (Figure 3B), and this enzyme was stable in the $\mathrm{pH}$ range of 3.0 to 9.5 (Figure 3B). The $\beta$-glucosidase activity was optimal at $65^{\circ} \mathrm{C}$ (Figure 3C); and after 1 hour of incubation, TkBgl3A retained more than $50 \%$ activity at $60^{\circ} \mathrm{C}$ (Figure 3C). The enzyme retained more than $90 \%$ activity for 360 hours at $\mathrm{pH} 4.0$ and $30^{\circ} \mathrm{C}$, which are the usual conditions for SSF of cellulose to produce ethanol (Figure 3D). The MichaelisMenten constant $\left(\mathrm{K}_{\mathrm{m}}\right)$ and maximal velocity $\left(\mathrm{V}_{\max }\right)$ for hydrolysis of pNPG were $1.21 \mathrm{mM}$ and $314 \mu \mathrm{mol} / \mathrm{min} /$ $\mathrm{mg}$, respectively. The catalytic constant $\left(\mathrm{K}_{\text {cat }}\right)$ was $523 / \mathrm{s}$. The enzyme was competitively inhibited by glucose, with an inhibition constant (Ki) value of $3.29 \mathrm{mM}$. 
M

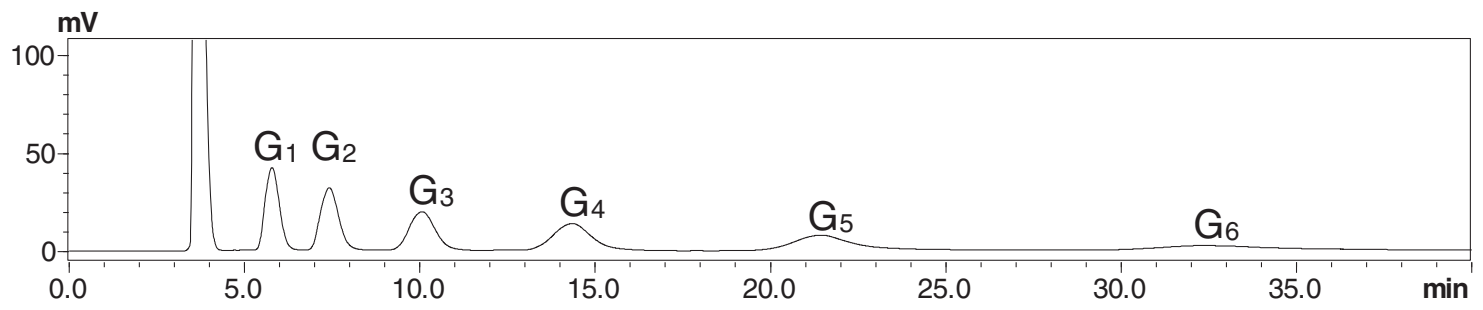

A

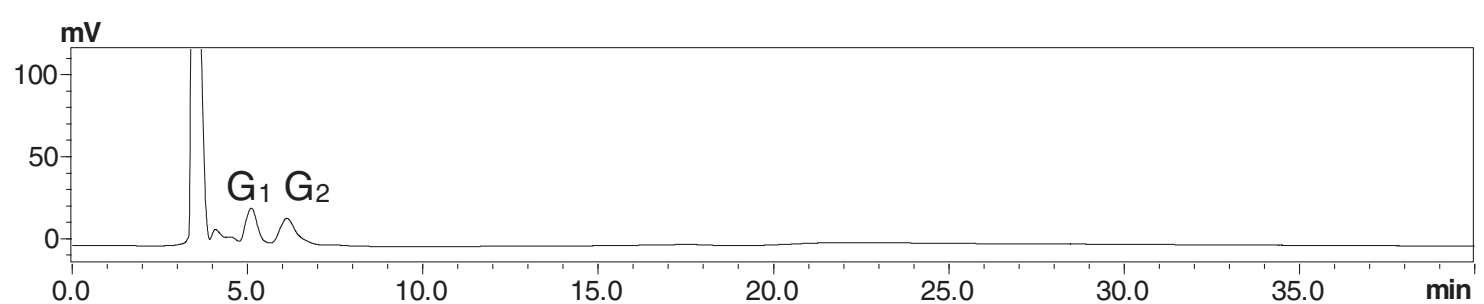

B

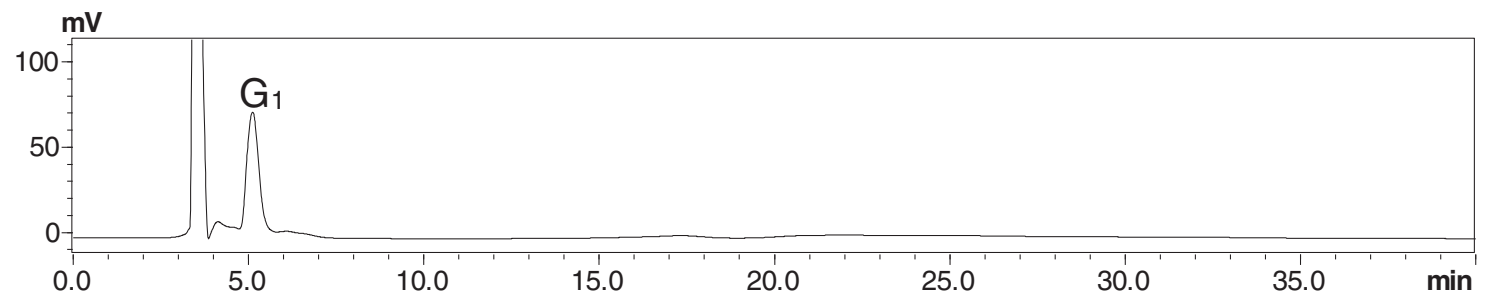

C

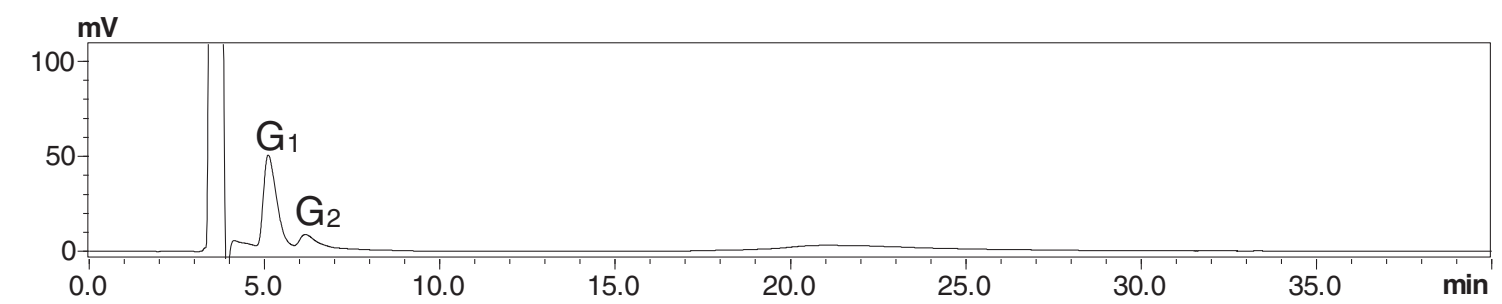

D

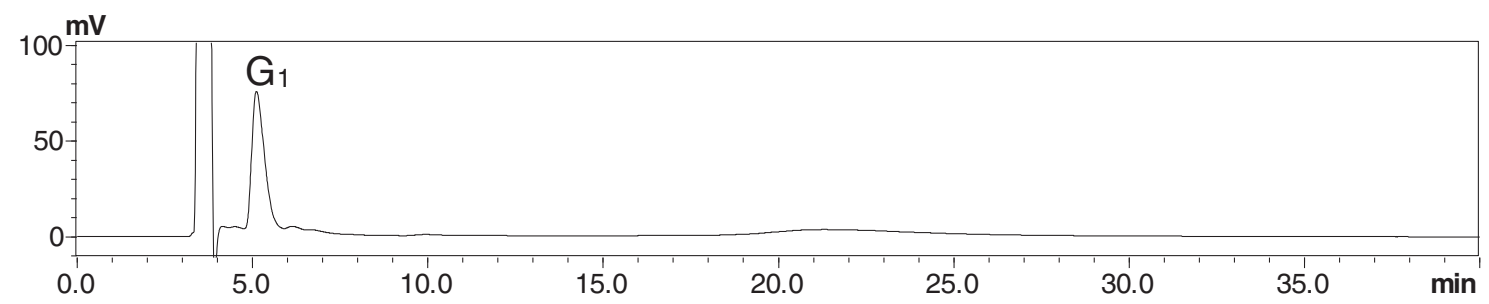

E

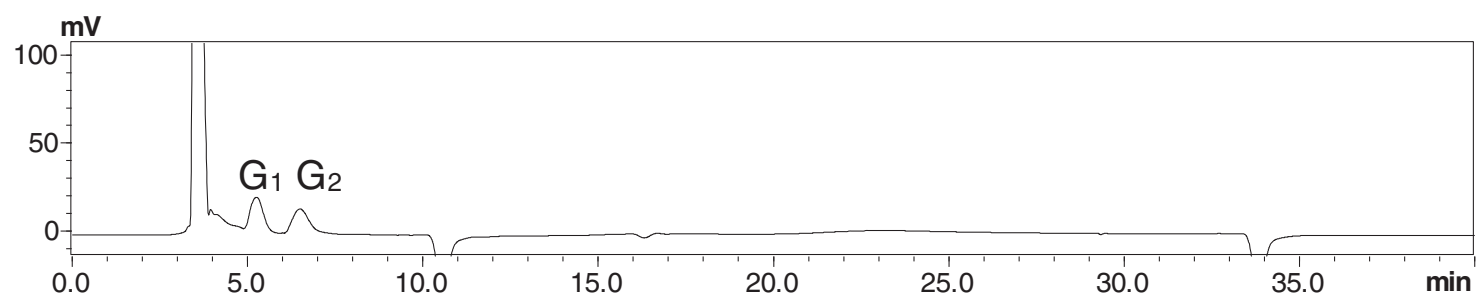

Figure 2 (See legend on next page.) 
(See figure on previous page.)

Figure 2 Analysis of hydrolytic products of Avicel by secretomes of four fungal strains by high-performance liquid chromatograpy. (A) Trichoderma reesei Rut-C30, (B) Trichoderma koningiopsis FCD3-1, (C) Hypocrea cremea BM48-3, (D) Trichoderma atroviride HP35-3, and (E) Trichoderma harzianum HP29-3. M: sugar standards including glucose (G1), cellobiose (G2), cellotriose (G3), cellotetraose (G4), cellopentose (G5), and cellohexose (G6). Enzyme load: $10 \mathrm{FPU} / \mathrm{g}$ Avicel; substrate concentration: 2\% Avicel. Hydrolysis was performed at pH 5.0 and $45^{\circ} \mathrm{C}$ for 32 hours. The results from samples incubated for $0,2,4,8,16$, and 32 hours, respectively, are provided in Additional file 2. FPU, filter paper units.

Specific activity of TkBgl3A toward cellobiose was 141.4 $\mathrm{U} / \mathrm{mg}$, which was significantly higher than that toward artificial substrate pNPG (108 U/mg) (Table 5). It is noteworthy that high-performance liquid chromatography (HPLC) analysis showed that the purified enzyme TkBgl3A could also hydrolyze cello-oligosaccharides (cellotriose, cellotetraose, cellopentaose, cellohexaose) and mainly produced glucose with high efficiency (see Additional file 3).

Metal ions had no significant effect on TkBgl3A when using pNPG as substrate, whereas the surfactant SDS significantly inhibited the activity of TkBgl3A. The reaction mix containing $0.25 \%$ SDS retained $13.5 \%$ of enzyme activity relative to the untreated sample (see Additional file 4).

\section{Discussion}

We carried out large-scale isolation and screening of secretomes with Avicelase activity from fungal strains isolated from tropical and subtropical forests in China. Kaisa et al. isolated approximately 600 mesophilic lignocellulolytic fungi from soil samples and decaying plant materials, and found that the majority of these strains were Trichoderma spp., with two Penicillium strains also found to be
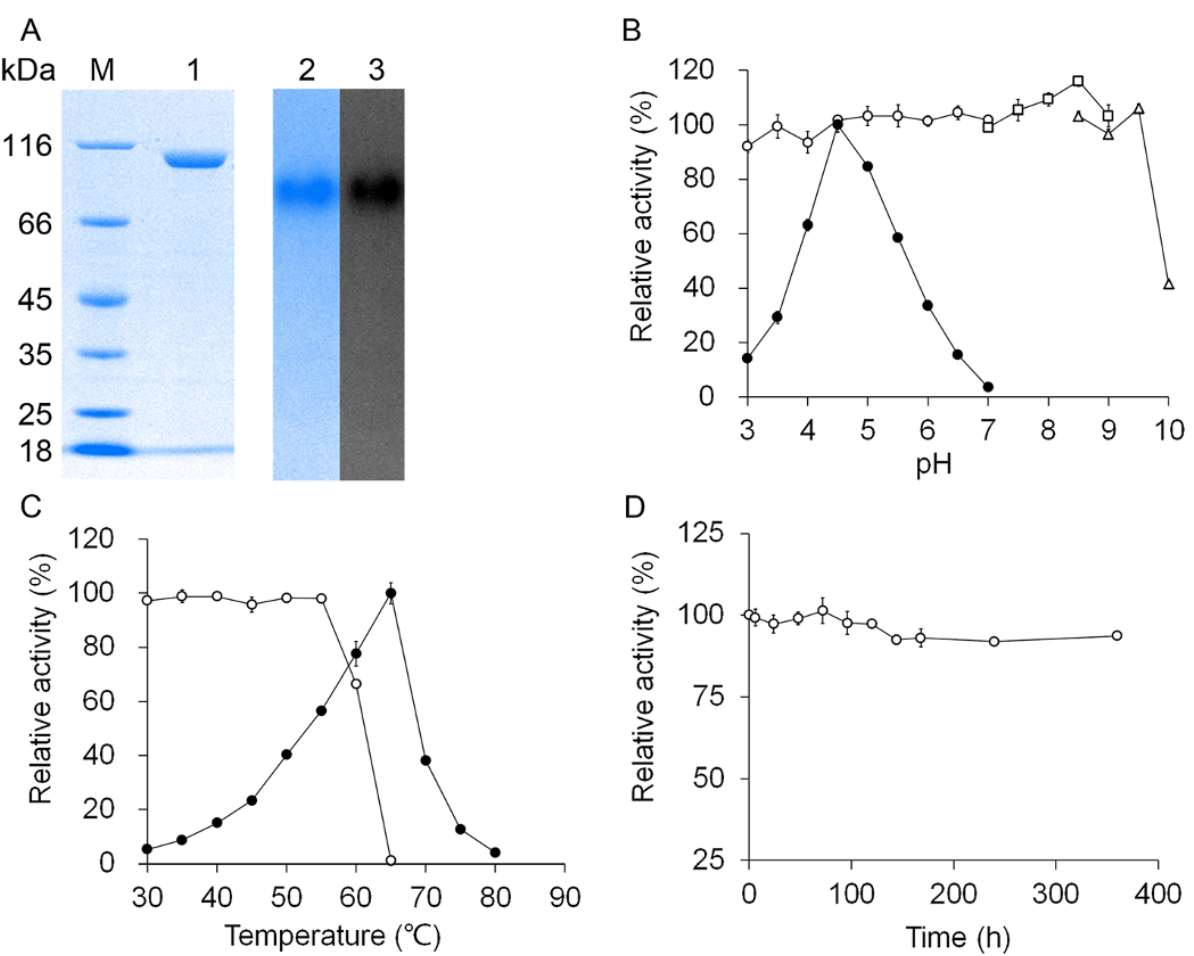

Figure 3 Identification of purified $\beta$-glucosidase from Trichoderma koningiopsis FCD3-1. (A) (Left) SDS-PAGE analyses of the $\beta$-glucosidase. Lane M, protein molecular marker; lane 1, the purified $\beta$-glucosidase. (Right) Native PAGE analyses of the $\beta$-glucosidase. Lane 2, the gel stained with Coomassie blue; lane 3, the gel soaked in a $50^{\circ} \mathrm{C}$ solution containing $0.1 \%$ esculin and $0.25 \%$ ammonium iron (III) citrate (pH 4.5) for 30 minutes. (B) Effect of pH on TkBgl3A activity and stability toward substrate pNPG. For effect of pH on TkBgl3A activity (filled circles), enzyme activity was measured in $0.1 \mathrm{M}$ citrate-phosphate buffer (CPB) pH 3.0 to 7.0 for 10 minutes at $50^{\circ} \mathrm{C}$. For effect of pH on TkBgl3A stability, the enzyme was incubated in $\mathrm{CPB}, \mathrm{pH} 3.0$ to 7.0 (open circles), or $0.1 \mathrm{M}$ Tris-HCl buffer, pH 7.0 to 9.0 (open squares), or $0.1 \mathrm{M}$ glycine-NaOH buffer, pH 8.5 to 10.0 (open triangles) at $4^{\circ} \mathrm{C}$ for 24 hours. The residual activity was measured under optimal conditions. All values are expressed as percentages of the activity of untreated sample. (C) Effect of temperature on TkBgl3A activity and stability toward substrate pNPG. To assess the effect of temperature on TkBgl3A activity (filled circles), enzyme activity was measured at pH 4.5 in $0.1 \mathrm{M} \mathrm{CPB}$ at the indicated temperature for 10 minutes. To assess the effect of temperature on TkBgl3A stability (open circles), the enzyme was incubated in $0.1 \mathrm{M} \mathrm{CPB} \mathrm{(pH} \mathrm{4.5)} \mathrm{at} \mathrm{various} \mathrm{temperatures} \mathrm{for} 1$ hour; the residual enzyme activity was measured under optimal conditions. All values are expressed as percentages of the activity of untreated sample. (D) Stability of TkBgl3A under SSF conditions ( $30^{\circ} \mathrm{C}$ and $\left.\mathrm{pH} 4.0\right) ; 100 \mu \mathrm{l}$ of purified enzyme was added to $4.9 \mathrm{ml}$ of $0.1 \mathrm{M} \mathrm{CPB} \mathrm{(pH} \mathrm{4.0),} \mathrm{followed} \mathrm{by} \mathrm{incubating} \mathrm{the} \mathrm{enzyme} \mathrm{mixture} \mathrm{at}$ $30^{\circ} \mathrm{C}$ for varying times before checking the remaining enzyme activity. 
Table 4 The matched peptide sequences to the mass spectra of the peptides released from TkBgl3A

\begin{tabular}{llll}
\hline Peptide sequence & Species & Accession no. & Annotation \\
\hline LGFPGLCNQDSPLGVR & Trichoderma virens Gv29-8 & EHK21862 & GH family 3 protein \\
GKGVDTQLGPVAGPIGR & T. virens GV29-8 & EHK21862 & GH family 3 protein \\
HFIGNEQEHYR & T. virens Gv29-8 & EHK21862 & GH family 3 protein \\
LDDMVR & T. virens GV29-8 & EHK21862 & GH family 3 protein \\
SIAVIGNDAHDNPAGPNACSDR & T. virens Gv29-8 & EHK21862 & GH family 3 protein \\
VAPAGGAPGGNPGLYDVLYTVTAQIENTGK & T. virens GV29-8 & EHK21862 & GH family 3 protein \\
GFDDIEILPGR & T. virens GV29-8 & EHK21862 & GH family 3 protein \\
TVYVGSSR & T. virens Gv29-8 & EHK21862 & GH family 3 protein \\
\hline
\end{tabular}

good cellulase producers [25]. The predominance of Trichoderma and Penicillium strains in hydrolyzing cellulose in Guangxi and Yunnan Provinces indicated that fungal strains from these two genera may play important roles in cellulose degradation and therefore in carbon recycling in tropical and subtropical forest soils in China.

Several experimental studies have concluded that effect of the physical properties of cellulose on cellulase binding and substrate accessibility by the enzyme is responsible for the rate of hydrolysis of lignocellulose by cellulase. Physical properties of cellulose include crystallinity, degree of polymerization, and accessible surface area [26-28]. Crystalline cellulose is the main form of cellulose in most plant cell walls, and crystallinity is a key factor affecting hydrolysis of cellulose because the glycosidic bonds in crystalline regions are difficult to be hydrolyzed compared with those in amorphous regions [27,28]. Avicel is one form of crystalline cellulose with a high degree of crystallinity, and it is very difficult to be hydrolyzed [29].

Desrchers et al. reported a fungal strain that can produce an enzyme complex with high carboxymethycellulase and cellobiase activity but low Avicelase activity $(0.02 \mathrm{U} / \mathrm{ml})$ [30]. Whereas the Avicelase activity produced by an actinomycete strain isolated by $\mathrm{Li}$ et al. was only $0.008 \mathrm{U} / \mathrm{ml}$ [31], Douglas et al. isolated a fungal strain with higher Avicelase activity ( 0.12 to $0.17 \mathrm{U} / \mathrm{ml})$ [32]. In the present study, $17 \%$ of the strains isolated using Whatman No. 1

Table 5 Substrate specificity of the purified $\beta$-glucosidase produced by $T$. koningiopsis FCD3-1

\begin{tabular}{lll}
\hline $\begin{array}{l}\text { Substrate } \\
\text { (concentration } \mathbf{1 ~} \mathbf{~ m M} \text { ) }\end{array}$ & $\begin{array}{l}\text { Specific activity, } \\
\mathbf{U} / \mathbf{m g}^{\mathbf{a}}\end{array}$ & $\begin{array}{l}\text { Relative } \\
\text { activity, \% }\end{array}$ \\
\hline pNPG & $108.0 \pm 1.3$ & $100 \pm 1.2$ \\
Cellobiose & $141.4 \pm 3.9$ & $124.22 \pm 2.76$ \\
Cellotriose & $99.9 \pm 0.7$ & $85.70 \pm 0.7$ \\
Cellotetraose & $91.9 \pm 4.6$ & $78.86 \pm 5.0$ \\
Cellopentaose & $84.4 \pm 0.8$ & $72.41 \pm 0.9$ \\
Cellohexaose & $88.6 \pm 1.5$ & $76.02 \pm 1.7$ \\
\hline
\end{tabular}

${ }^{a}$ Data are means \pm standard deviation from three replicates. The experiments were repeated three times, and similar results were obtained. filter paper as the sole carbon source had significant Avicelase activity (greater than $0.05 \mathrm{U} / \mathrm{ml}$ ), and $10 \%$ of the strains had Avicelase activity greater than $0.2 \mathrm{U} / \mathrm{ml}$, which is a high proportion of strains producing high levels of Avicelase activity.

T. koningiopsis FCD3-1 was the best-performing isolate, producing a similar level of Avicelase activity to T. reesei Rut-C30. Interestingly, strain FCD3-1 produced about 17 times as much $\beta$-glucosidase as $T$. reesei RutC30. Although $T$. reesei has been extensively studied and reported to produce a highly active extracellular cellulase system, most of its strains produce $\beta$-glucosidase at low levels compared with other cellulolytic fungi such as Aspergillus species, because most of its $\beta$-glucosidase is bound to its cell wall. Exogenous supplementation of $\beta$-glucosidase in $T$. reesei cellulase preparations has been used as an alternative strategy to increase the rate and extent of cellulose hydrolysis [33]. Nevertheless, wild-type Trichoderma strains producing significant quantities of $\beta$ glucosidase have been reported. Kov́acs et al. screened more than 150 wild-type Trichoderma strains isolated from 30 countries based on the overall cellulase production (filter paper activity). Trichoderma atroviride TUB F-1505 was the best wild-type extracellular cellulase producer, producing significant quantities of $\beta$-glucosidase, but it had 10 to $25 \%$ less extracellular cellulase activity than T. reesei Rut-C30. TUB F-1505 was isolated from a tropical rain forest soil sample collected near Manaus, close to the Rio Negro, Brazil [34]. Cellulase production by six species of Trichoderma cultivated on medicinal plant processings was comparatively evaluated, and Trichoderma citrinoviride MTCC No. 2418 was found to be the most efficient producer of cellulases and also produced a high level of $\beta$-glucosidase. T. citrinoviride produced five times more $\beta$-glucosidase than produced by $T$. reesei MTCC No. 164 [35]. However, purification of $\beta$-glucosidase and cloning of the gene encoding the enzyme from T. atroviride and T. citrinoviride were not reported.

In the present study, the purified $\beta$-glucosidase TkBgl3A was most active at $\mathrm{pH} 4.5$. Most fungal $\beta$-glucosidases have an optimal $\mathrm{pH}$ range of 3.5 to 6.5 [36]. The optimal 
$\mathrm{pH}$ for the $\beta$-glucosidase was similar to the commercial $\beta$-glucosidase Novozyme S188 [37]. TkBgl3A was stable at $\mathrm{pH} 3.0$ to 9.5 , and its activity did not vary substantially within this range; its $\mathrm{pH}$ stability was notably better than that of previously reported $\beta$-glucosidases [21]. TkBgl3A had an optimum temperature of $65^{\circ} \mathrm{C}$; in general, the optimum temperatures for fungal $\beta$-glucosidases are in the range of 50 to $70^{\circ} \mathrm{C}$ [21]. In addition, $\mathrm{TkBgl} \mathrm{A}$ displayed good thermostability, similar to Bgl3A from P. funiculosum NCL1 [38].

Most microbial $\beta$-glucosidases have glucose Ki ranging from as low as $0.5 \mathrm{mM}$ to $100 \mathrm{mM}$ or more [14]. Although glucose acted as a competitive inhibitor of pNPG hydrolysis by TkBgl3A, with a $\mathrm{Ki}$ of $3.29 \mathrm{mM}$, the glucose inhibition of $\beta$-glucosidase could be overcome by an SSF process in which glucose is rapidly converted to ethanol by yeast [39]. The purified TkBgl3A was stable under SSF conditions, which facilitates the use of the enzyme in SSF.

TkBgl3A exhibited a similar affinity toward the synthetic substrate pNPG $(1.21 \mathrm{mM})$ as that of the commercially available $\beta$-glucosidase Novozyme S188 (1.03 mM). However, the specific activity of TkBgl3A for cellobiose was approximately four times higher than that of Novozyme S188 [16]. The higher activity of TkBgl3A toward cellobiose and cello-oligosaccharides again supports the potential application of the enzyme in the final step of cellulose saccharification $[40,41]$.

\section{Conclusions}

Large-scale isolation and screening of secretomes with Avicelase activity for fungal strains from tropical and subtropical forests in China led to the isolation and identification of 31 fungal strains producing Avicelase activity of greater than $0.2 \mathrm{U} / \mathrm{ml}$ in liquid cultivation. All 31 fungal strains were identified as Trichoderma or Penicillium species, indicating the predominance of these genera in cellulose degradation in subtropical and tropical forests in China. T. koningiopsis FCD3-1 was the most efficient producer of cellulases and also had a high level of extracellular $\beta$-glucosidase. The purified $\beta$-glucosidase TkBgl3A from FCD3-1 showed high specific activity toward natural substrate cellobiose and good stability under SSF conditions, indicating its potential application in SSF of cellulose to produce bioethanol.

\section{Methods}

\section{Collection of soil and rotten wood samples}

Soil and rotten wood in virgin forests were collected in 2007 and 2008 (July to October) from eight natural reserves in both tropical and subtropical areas in different biotopes in China. The sampling route was set at intervals of 100 meters, with one sample collected per interval. Surface soil at sampling sites was removed, and the soil at a depth of 50 to $200 \mathrm{~mm}$ was collected, with about $50 \mathrm{~g}$ per sample.

\section{Cultivation and isolation of fungal strains}

The suspensions of soil samples were serially diluted. Three dilutions of each sample were chosen, and $0.1 \mathrm{ml}$ of each sample was spread onto the surface of Medium $\mathrm{P}$ agar plates containing Whatman No. 1 filter paper as the sole carbon source. The composition of Medium $\mathrm{P}$ was as follows: $2 \mathrm{~g} / \mathrm{l} \mathrm{NaNO}_{3}, 0.5 \mathrm{~g} / \mathrm{l} \mathrm{MgSO}_{4} \cdot 7 \mathrm{H}_{2} \mathrm{O}, 0.5 \mathrm{~g} / \mathrm{l}$ $\mathrm{NaCl}, 0.01 \mathrm{~g} / \mathrm{l} \mathrm{FeSO} \cdot 7 \mathrm{H}_{2} \mathrm{O}, 1.0 \mathrm{~g} / \mathrm{KH}_{2} \mathrm{PO}_{4}, 0.4 \mathrm{~g} / \mathrm{l}$ yeast, extract, $10 \mathrm{~g} / \mathrm{l}$ Whatman No. 1 filter paper, and $15.0 \mathrm{~g} / \mathrm{l}$ agar, at $\mathrm{pH}$ 5.0. After incubation at $28^{\circ} \mathrm{C}$ for 3 to 5 days, the single colonies of fungi were picked using an inoculating hook and inoculated onto a new Medium P agar plate.

\section{Shake-flask cultivation of fungal strains}

The medium used for the shake-flask cultivation was named Medium A, and contained microcrystalline cellulose powder (Avicel PH101, Sigma, St. Louis, MO, USA) as the sole carbon source. The composition of Medium A was as follows: $10 \mathrm{~g} / \mathrm{l}$ Avicel (Sigma, USA), $2 \mathrm{~g} / \mathrm{l}$ $\mathrm{KH}_{2} \mathrm{PO}_{4}, 1.4 \mathrm{~g} / \mathrm{l}\left(\mathrm{NH}_{4}\right)_{2} \mathrm{SO}_{4}, 0.3 \mathrm{~g} / \mathrm{MgSO}_{4} \cdot 7 \mathrm{H}_{2} \mathrm{O}, 0.3$ $\mathrm{g} / \mathrm{l} \mathrm{CaCl}_{2}, 1 \mathrm{~g} / \mathrm{l} \mathrm{CaCO}, 1 \mathrm{~g} / \mathrm{l}$ peptone (Difco, USA), $1 \mathrm{~g} / \mathrm{l}$ Tween-80, $0.3 \mathrm{~g} / \mathrm{l}$ urea, $10 \mathrm{mg} / \mathrm{l} \mathrm{FeSO} 4 \cdot 7 \mathrm{H}_{2} \mathrm{O}, 3.2 \mathrm{mg} / \mathrm{l}$ $\mathrm{MnSO}_{4}, 6.9 \mathrm{mg} / \mathrm{l} \mathrm{ZnSO} 4 \cdot 7 \mathrm{H}_{2} \mathrm{O}$, and $0.4 \mathrm{mg} / \mathrm{l} \mathrm{CoCl}_{2}$. $6 \mathrm{H}_{2} \mathrm{O}$. All materials were supplied by Sinopharm Chemical Reagent Co., Ltd., Shanghai, China unless otherwise stated. The $\mathrm{pH}$ was adjusted to 5.0 before sterilization.

Shake-flask cultivation was carried out in $500 \mathrm{ml}$ cotton-plugged Erlenmeyer flasks containing $100 \mathrm{ml}$ of Medium A. After autoclaving at $121^{\circ} \mathrm{C}$ for 20 minutes, the flasks were inoculated by removing the mycelia from a single colony of fungi on a Medium $\mathrm{P}$ agar plate. Flask cultivation was performed at $28^{\circ} \mathrm{C}$ on a rotary shaker at $200 \mathrm{rpm}$. After 3 days of cultivation, samples were removed and centrifuged at $4^{\circ} \mathrm{C}$ and $9,000 \times$ g (Centrifuge Model:himac CF 16RX, Rotor type: T15A29, Hitachi Koki Co., Ltd., Tokyo, Japan) for 10 minutes, and the clear supernatants were removed and used for enzyme assays.

\section{Enzyme assay}

Avicelase activity produced by isolated fungal strains was determined using the 3,5-dinitrosalicylic acid (DNS) method [42]. The reaction system was prepared by mixing $50 \mu \mathrm{l}$ of crude enzyme (appropriately diluted) with $450 \mu \mathrm{l}$ of $1.1 \%(\mathrm{w} / \mathrm{v})$ Avicel. The buffer used for resuspending the substrate was $0.1 \mathrm{M}$ sodium citrate buffer at appropriate $\mathrm{pH}$. The mixtures were incubated at $50^{\circ} \mathrm{C}$ for 1 hour, and then the reactions were stopped by adding $1 \mathrm{ml}$ of DNS reagent. All mixtures were heated in boiling water for 5 minutes for color development. Subsequently, $200 \mu \mathrm{l}$ of each sample was transferred to a 96-well microplate, and 
absorbance was measured at $540 \mathrm{~nm}$. $1 \mathrm{U}$ of Avicelase activity was defined as the amount of enzyme that released $1 \mu \mathrm{mol}$ of reducing sugars equivalent to glucose per minute during the reaction.

The enzyme activities toward filter paper and $\mathrm{CMC}-\mathrm{Na}$ were determined as described by Ghose [43]. $\beta$-glucosidase activity was measured using Berghem's method [44].

To determine the optimal $\mathrm{pH}$ of the crude enzyme produced by isolated fungal strains, $50 \mu \mathrm{l}$ of supernatant from flask cultivation were incubated with $450 \mu \mathrm{l}$ of Avicel $(1.1 \% \mathrm{w} / \mathrm{v})$ at $50^{\circ} \mathrm{C}$ with a range of different $\mathrm{pH}$ levels $(3.0$ to 6.0 at intervals of 0.5 ). To determine the optimal temperature of crude enzyme produced by isolated fungal strains, $50 \mu \mathrm{l}$ of supernatant from flask cultivation were incubated with $450 \mu \mathrm{l}$ of Avicel $(1.1 \%$, w/v) at the optimal $\mathrm{pH}$ and a temperature range of 30 to $65^{\circ} \mathrm{C}$ with an interval of $5^{\circ} \mathrm{C}$. The maximum Avicelase activity obtained at different $\mathrm{pH}$ or temperature levels was considered to be $100 \%$.

Hydrolysis products of Avicel by the crude enzymes produced by fungal strains FCD3-1, BM48-3, HP35-3, HP29-3, and Rut-C30 were analyzed by HPLC. After 5 days of shaking cultivation at $28^{\circ} \mathrm{C}$ in $500 \mathrm{ml}$ cottonplugged Erlenmeyer flasks containing $100 \mathrm{ml}$ of Medium $A$, the cultures of fungal strains were centrifuged at 3,000 $\times$ g (Centrifuge Model:himac CF 16RX, Rotor type: T5SS31, Hitachi Koki Co., Ltd., Tokyo, Japan) for 10 minutes, and the filter paper activity of each collected supernatant was measured. Each enzyme solution was respectively added to $100 \mathrm{mg}$ of Avicel in a test tube at a dose of $10 \mathrm{U} / \mathrm{g}$ Avicel and the total volume of the mixture was adjusted to $5 \mathrm{ml}$ with $0.1 \mathrm{M}$ citratephosphate buffer (CPB) at $\mathrm{pH}$ 5.0. The hydrolysis was performed in a water bath shaker with shaking at 200 $\mathrm{rpm}$ at $45^{\circ} \mathrm{C}$. Hydrolysis was stopped after reactions were conducted for $0,2,4,8,16$ and 32 hours by boiling for 10 minutes. After the cooled sample was filtered through a $0.22 \mu \mathrm{m}$ filter (Nylon 66 Syringe Filter, Jinteng, China), the collected filtrate was analyzed with HPLC (LC-10A VP Plus, Shimadzu Kyoto, Japan) equipped with a refractive index detector (Shimadzu). Sugars were separated using a Hypersil $\mathrm{NH}_{2}$ column (Dalian Elite Analytical Instruments Co., Ltd., China) at $30^{\circ} \mathrm{C}$, with $75 \%$ acetonitrile as eluent, at a flow rate of $1.0 \mathrm{ml} / \mathrm{min}$.

\section{Identification of isolated fungal strains}

Cell mycelia of fungal isolates were obtained from pure culture in Yeast Mold (YM) broth (10 g/l glucose, $3 \mathrm{~g} / \mathrm{l}$ yeast extract, $3 \mathrm{~g} / \mathrm{l}$ malt extract, and $5 \mathrm{~g} / \mathrm{l}$ peptone). Genomic DNA of the isolates was extracted and used as PCR template. PCR was performed to amplify the ITS (approximately $600 \mathrm{bp}$, including ITS1, the $5.8 \mathrm{~S}$ rRNA gene, and ITS2 region) of fungal ribosomal DNA with primers ITS1 5'-TCCGTAGGTGAACCTGCGG-3' and ITS4 5'-TC CTCCGCTTATTGATATGC-3'. The $25 \mu \mathrm{l}$ mixtures were composed of $1 \mu \mathrm{l}$ of template DNA, $12.5 \mu \mathrm{l}$ of $2 \times$ Taq PCR Master Mix (purchased from Tiangen Biotech, Beijing, China; containing 0.5 U Taq DNA poly-

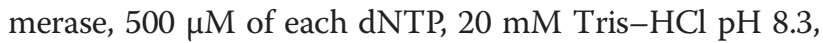
$100 \mathrm{mM} \mathrm{KCl}, 3 \mathrm{mM} \mathrm{MgCl}$, and bromophenol blue), $1 \mu \mathrm{l}$ of each primer $(10 \mu \mathrm{M})$ and $9.5 \mu \mathrm{l}$ of double-distilled $\mathrm{H}_{2} \mathrm{O}$. The PCR procedure was as follows: primary denaturation for 5 minutes at $94^{\circ} \mathrm{C}$, followed by 30 cycles of denaturation at $94^{\circ} \mathrm{C}$ for 30 seconds, annealing at $55^{\circ} \mathrm{C}$ for 30 seconds, and extension at $72^{\circ} \mathrm{C}$ for 60 seconds, then an additional reaction for 10 minutes at $72^{\circ} \mathrm{C}$. The PCR products were separated in $0.8 \%$ agarose gels to confirm purity, quantity, and size, and sent to Sangon Biotech (Shanghai) Co., Ltd. (China) for sequencing. The ITS sequences were compared with other ITS sequences in GenBank using the BlastN program (http://blast.ncbi.nlm.nih.gov/Blast.cgi).

\section{Media and culture conditions for cultivation of T. koningiopsis FCD3-1}

The media used for cultivation of T. koningiopsis FCD3-1 were potato dextrose agar (PDA), Avicel agar medium, or fungal cultivation medium. The Avicel agar medium contained: 3 g Avicel PH-101 (Sigma), $2.0 \mathrm{~g} \mathrm{KH}_{2} \mathrm{PO}_{4}, 1.4 \mathrm{~g}$ $\left(\mathrm{NH}_{4}\right)_{2} \mathrm{SO}_{4}, 0.3 \mathrm{~g} \mathrm{MgSO}_{4} \cdot 7 \mathrm{H}_{2} \mathrm{O}, 0.3 \mathrm{~g} \mathrm{CaCl}, 5 \mathrm{mg}$ $\mathrm{FeSO}_{4} \cdot 7 \mathrm{H}_{2} \mathrm{O}, 1.6 \mathrm{mg} \mathrm{MnSO}_{4}, 1.7 \mathrm{mg} \mathrm{ZnCl}, 2 \mathrm{mg} \mathrm{CoCl}$, and $20 \mathrm{~g}$ agar in 1 litre ultra-pure water. The fungal cultivation medium contained: $4.0 \mathrm{~g} \mathrm{KH}_{2} \mathrm{PO}_{4}, 2.8 \mathrm{~g}\left(\mathrm{NH}_{4}\right)$ ${ }_{2} \mathrm{SO}_{4}, 0.6 \mathrm{~g} \mathrm{MgSO}_{4} \cdot 7 \mathrm{H}_{2} \mathrm{O}, 0.6 \mathrm{~g} \mathrm{CaCl}_{2}, 0.6 \mathrm{~g}$ urea, $10 \mathrm{mg}$ $\mathrm{FeSO}_{4} \cdot 7 \mathrm{H}_{2} \mathrm{O}, 3.2 \mathrm{mg} \mathrm{MnSO}_{4}, 2.8 \mathrm{mg} \mathrm{ZnSO}_{4}, 2.4 \mathrm{mg}$ $\mathrm{CoCl}_{2}, 20 \mathrm{~g}$ wheat bran, and $30 \mathrm{~g}$ Avicel PH-101 in 1 litre of ultra-pure water. Each medium was adjusted to pH 5.0.

To cultivate the T. koningiopsis FCD3-1 for high-level production of $\beta$-glucosidase, FCD3-1 was firstly inoculated onto PDA plates at $28^{\circ} \mathrm{C}$ for 72 hours. The hyphae were then incubated in Avicel agar medium at $28^{\circ} \mathrm{C}$ for 96 hours, and incubated in fungal cultivation medium at $28^{\circ} \mathrm{C}$ on a rotary shaker at $200 \mathrm{rpm}$ for 1 week to assess extracellular $\beta$-glucosidase production.

\section{Purification and characterization of one $\beta$-glucosidase secreted by $T$. koningiopsis FCD3-1}

The culture of FCD3-1 was centrifuged for 20 minutes at 9,000 $\times$ g (Centrifuge Model:himac CF 16RX, Rotor type: T15A29, Hitachi Koki Co., Ltd., Tokyo, Japan) and $4{ }^{\circ} \mathrm{C}$ after cultivation. The supernatant was carefully transferred to a sanitized container. Purification of $\beta$-glucosidase was mainly based on the methods of Parry et al. [45]. The supernatant (crude enzyme) was subjected to $40 \%$ $\left(\mathrm{NH}_{4}\right)_{2} \mathrm{SO}_{4}$ precipitation. After centrifugation, the supernatant was collected and then subjected to $60 \%\left(\mathrm{NH}_{4}\right)$ ${ }_{2} \mathrm{SO}_{4}$ precipitation overnight. The precipitated protein was dissolved in $1.5 \mathrm{M}\left(\mathrm{NH}_{4}\right)_{2} \mathrm{SO}_{4}$ solution and loaded onto a HiPrep 16/10 Phenyl FF (high sub) column (GE Healthcare, Amersham Place, Buckinghamshire, UK). The eluted 
$\beta$-glucosidase was then loaded on an anion column (5 ml HiTrap $^{\text {Tw }}$ Q FF, GE Healthcare, UK).

The purified protein sample was separated by SDSPAGE and the protein band was excised. The band pieces were washed with $100 \mu \mathrm{ld} \mathrm{dH}_{2} \mathrm{O}$ for 15 minutes and were further successively washed for 10 minutes

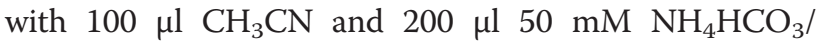
$\mathrm{CH}_{3} \mathrm{CN}(50: 50 \mathrm{v} / \mathrm{v})$. After the band pieces were treated with $100 \mu \mathrm{l}$ of $\mathrm{CH}_{3} \mathrm{CN}$ to dehydrate the proteins for 10 minutes, the band pieces were treated with $20 \mu \mathrm{l}$ of $10 \mathrm{ng} / \mu \mathrm{l}$ modified trypsin in $20 \mathrm{mM} \mathrm{NH}_{4} \mathrm{HCO}_{3}$ for 30 minutes, then more $20 \mathrm{mM} \mathrm{NH} \mathrm{NHCO}_{3}$ was added to cover the band pieces. After overnight incubation at $37^{\circ} \mathrm{C}$, an equal volume of $\mathrm{CH}_{3} \mathrm{CN}$ was added. After incubation at room temperature for 30 minutes and centrifugation, the supernatant was transferred to a new clean Eppendorf tube, and then lyophilized by vacuum centrifugation and stored at $-80^{\circ} \mathrm{C}$.

Liquid chromatography was performed on a nano Acquity UPLC system (Waters Corporation, Milford, USA) connected to a LTQ Orbitrap XL mass spectrometer (Thermo Scientific, Bremen, Germany) equipped with an online nano-electrospray ion source (Michrom Bioresources, Auburn, USA). Peptides were resuspended with $25 \mu \mathrm{l}$ of solvent A (5\% acetonitrile and $0.1 \%$ formic acid in water), then $20 \mu \mathrm{l}$ of peptide solution, was loaded onto a Captrap Peptide column $(0.5 \mathrm{~mm}$ internal diameter $\times 2.0 \mathrm{~mm}$; Michrom Bioresources) using a $20 \mu \mathrm{l} / \mathrm{min}$ flow rate of solvent A for 5 minutes, and then separated on a Magic C18AQ reverse phase column $(100 \mu \mathrm{m}$ internal diameter $\times 15 \mathrm{~cm}$; Michrom Bioresources) with a linear gradient, starting from $5 \%$ solvent B $(90 \%$ acetonitrile and $0.1 \%$ formic acid in water) to $45 \% \mathrm{~B}$ (that is, from $95 \%$ A to $55 \%$ A) in 70 minutes. The column flow rate was maintained at $500 \mathrm{nl} / \mathrm{min}$ and column temperature at $35^{\circ} \mathrm{C}$. An electrospray voltage of $1.4 \mathrm{kV}$ versus the inlet of the mass spectrometer was used.

A LTQ Orbitrap XL mass spectrometer was operated in the data-dependent mode to switch automatically between MS and MS/MS acquisition. Survey full-scan MS spectra with one microscan (350 to $1600 \mathrm{~m} / \mathrm{z}$ ) was acquired in the Obitrap with a mass resolution of 100,000 at $400 \mathrm{~m} / \mathrm{z}$, followed by MS/MS of the eight most intense peptide ions in the LTQ analyzer. The automatic gain control (AGC) was set to $1,000,000$ ions, with maximum accumulation times of $500 \mathrm{~ms}$. For MS/MS, we used an isolation window of $2 \mathrm{~m} / \mathrm{z}$, and the AGC of LTQ was set to 20000 ions, with maximum accumulation time of $120 \mathrm{~ms}$. Single charge state was rejected, and dynamic exclusion was used with two microscans using exclusion durations of 10 and 90 seconds. For MS/MS, precursor ions were activated using 35\% normalized collision energy at the default activation q of 0.25 and an activation time of $30 \mathrm{~ms}$. The spectra were recorded with Xcalibur (v2.0.7) software.
The mass spectra were searched using the Mascot Daemon software (v2.3.0; Matrix Science, London, UK) based on the Mascot algorithm. We searched the National Center for Biotechnology Information database (downloaded on 27 March 2013, taxonomy is Trichoderma with 39.001 entries). To reduce false-positive identification results, a decoy database containing the reverse sequences was appended to the database. The searching parameters were set up as follows: full trypsin cleavage with two missed cleavages was considered; oxidation on methionine and aceytlation of the protein $\mathrm{N}$-terminus were set as variable modifications.; the peptide mass tolerance was 10 ppm; and the fragment ion tolerance was 1.0 Da. Peptides for which Mascot scores exceeded the $99.9 \%$ confidence level score (ions score $\geq 40$ ) were accepted as correct matches.

\section{Protein and enzyme activity assay of $\beta$-glucosidase secreted by $T$. koningiopsis FCD3-1}

Determination of the total protein was performed according to the method of Branford [46]. Standard curves were prepared with bovine serum albumin. For enzyme assay, each reaction was performed at $50^{\circ} \mathrm{C}$ and $\mathrm{pH} 5.0$ (in triplicate if not otherwise mentioned). The reaction mixture was $116 \mu \mathrm{l}$ of $0.1 \mathrm{M} \mathrm{CPB}(\mathrm{pH} 5.0), 14 \mu \mathrm{l}$ of substrate solution ( $25 \mathrm{mM} \mathrm{pNPG)} \mathrm{and} 10 \mu \mathrm{l}$ of enzyme solution. After addition of enzyme, the mixture was incubated for 10 minutes at $50^{\circ} \mathrm{C}$ and stopped with $70 \mu \mathrm{l}$ of $0.4 \mathrm{M} \mathrm{Na}_{2} \mathrm{CO}_{3}$. The developed color was read at $410 \mathrm{~nm}$ on a microplate reader (BioTek, USA). One unit of $\beta$-glucosidase activity was expressed as the amount of enzyme required to release $1 \mu \mathrm{mol}$ of $\mathrm{p}$-nitrophenol (pNP) per minute.

The optimal $\mathrm{pH}$ of $\beta$-glucosidase activity was determined by incubating the purified enzyme at $50^{\circ} \mathrm{C}$ for 10 minutes in $\mathrm{CPB}$ with $\mathrm{pH}$ values in the range of 3.0 to 7.0 at intervals of 0.5 . To determine the optimal temperature, the enzyme was incubated in $\mathrm{CPB}(0.1 \mathrm{M}$ and $\mathrm{pH} 4.5)$ for 10 minutes at different temperatures in the range of 30 to $80^{\circ} \mathrm{C}$ at intervals of $5^{\circ} \mathrm{C}$ [47].

The $\mathrm{pH}$ stability of purified enzyme was assessed by incubating $500 \mu \mathrm{l}$ of purified enzyme at $4^{\circ} \mathrm{C}$ for 24 hours in various buffers adjusted to different $\mathrm{pH}$ values, followed by checking the residual activity [17]. To determine the thermostability of $\beta$-glucosidase activity, the purified enzyme was incubated at different temperatures $\left(30,35,40,45,50,55,60\right.$, and $\left.65^{\circ} \mathrm{C}\right)$ in the absence of substrate. After incubation for 1 hour, the residual $\beta$-glucosidase activity was determined as described above. Stability of the purified enzyme under SSF conditions $\left(30^{\circ} \mathrm{C}\right.$ and $\mathrm{pH} 4.0$ ) was assessed by mixing $100 \mu \mathrm{l}$ of purified enzyme with $\mathrm{CPB} \mathrm{pH} 4.0$ to a volume of $5 \mathrm{ml}$, followed by incubating the enzyme mixture at $30^{\circ} \mathrm{C}$ for varying times before checking the remaining activity. 
The influence of metal ions on enzyme activity was determined by mixing the enzyme with $\mathrm{CPB}(\mathrm{pH} 4.5)$ that contained various metal ions and reagents.

The kinetic parameters $\left(\mathrm{V}_{\max }\right.$ and $\left.\mathrm{K}_{\mathrm{m}}\right)$ in hydrolysis of pNPG by the purified $\beta$-glucosidase were determined under optimal conditions, and the values for $\mathrm{K}_{\mathrm{m}}$ and $\mathrm{V}_{\max }$ were estimated by applying a nonlinear curve fit using GraphPad Prism4 from GraphPad Software (San Diego, CA, USA). Catalytic constants $\left(\mathrm{K}_{\text {cat }}\right)$ and catalytic efficiency ratios $\left(\mathrm{K}_{\mathrm{cat}} / \mathrm{K}_{\mathrm{m}}\right)$ were determined from the obtained kinetic parameter values [17].

The activity of the purified $\beta$-glucosidase against pNPG and cello-oligosaccharides (degree of polymerization from 2 to 6) was measured in $0.1 \mathrm{M} \mathrm{CPB} \mathrm{(pH} \mathrm{4.5)} \mathrm{at} 65^{\circ} \mathrm{C}$ for 10 minutes. For the hydrolysis of the pNPG, $250 \mu \mathrm{l}$ reaction mixtures were set up by adding $0.1 \mu \mathrm{g}$ purified enzyme and pNPG stock solution to final concentration of $1 \mathrm{mM}$. For hydrolysis of cello-oligosaccharides, $250 \mu \mathrm{l}$ reaction mixtures were set up by adding $0.28 \mu \mathrm{g}$ purified enzyme and cello-oligosaccharide to final concentration of $1 \mathrm{mM}$. The amount of released glucose was determined under the same conditions as described above using a glucose oxidase kit (Maker Co., Ltd., China). One unit of $\beta$-glucosidase activity was expressed as the amount of enzyme required to release $1 \mu \mathrm{mol}$ of $\mathrm{pNP}$ or glucose per minute [16]. In addition, the hydrolysates of cellooligosaccharides produced by the purified $\beta$-glucosidase TkBgl3A were analyzed by HPLC using a refractive index detector (RI detector k-2301; Knauer, Germany). Sugars were separated using a Hypersil $\mathrm{NH}_{2}$ column (Dalian Elite Analytical Instrument Co., Ltd., China) at $25^{\circ} \mathrm{C}$, with $70 \%$ acetonitrile as eluent, at a flow rate of $1.0 \mathrm{~mL} / \mathrm{min}$.

\section{Cloning of $T k b g / 3 A$ gene}

For isolation of genomic DNA from T. konigiopsis strain FCD3-1, the fungal strain was cultivated on PDA plates for 3 days. Genomic DNA was isolated from the lyophilized mycelia using the hexadecyl trimethyl ammonium bromide (CTAB) extraction method [48]. To amplify the TkBgl3A gene, the forward primer 5'-ATGTTGTCAA ATTCAATCATCGCCGTTG-3' and reverse primer 5' CTAAGGAAGAACCTGGCTCAAGGGTAAA-3' were used, which were designed based on the coding sequence (GenBank accession number ABDF02000059) of GH family 3 protein from $T$. virens GV29-8 using vector NTI 10 software. The extracted genomic DNA from T. konigiopsis FCD3-1 was used as template. The PCR amplification was carried out using the following condition: one cycle at $95^{\circ} \mathrm{C}$ for 4 minutes, followed by 30 cycles at $95^{\circ} \mathrm{C}$ for 30 seconds, $56^{\circ} \mathrm{C}$ for 30 seconds, and $72^{\circ} \mathrm{C}$ for 1.5 minutes, and then one cycle at $72^{\circ} \mathrm{C}$ for 10 minutes. The PCR product was cloned into the T-vector, and then transformed into Escherichia coli DH5 $\alpha$. Three of the transformants were sequenced by BGI TechSolutions Co.,
Ltd. (Shenzhen, China). The sequence analyses were carried out using the Lasergene DNASTAR software package, Vector NTI 10 software, NCBI-BLAST, and SMART (http://smart.embl-heidelberg.de).

\section{Nucleotide sequence accession numbers}

All the ITS sequences of the 31 fungal strains reported in this paper were deposited in the GenBank database under accession numbers KJ619589 to KJ619593 and KJ619599 to KJ619642. The $\beta$-glucosidase gene TkBgl3A is under GenBank accession number KJ623247.

\section{Additional files}

Additional file 1: Morphological characteristics of T. koningiopsis

FCD3-1.

Additional file 2: Analysis of hydrolytic products of Avicel by secretomes of four fungal strains by HPLC.

Additional file 3: The hydrolysates of cello-oligosaccharides by the purified $\beta$-glucosidase TkBgl3A at different time intervals.

Additional file 4: Effects of metal ions and reagents on enzyme activity of the purified $\beta$-glucosidase produced by $T$. koningiopsis FCD3-1.

\section{Competing interests}

The authors declare that they have no competing interests.

\section{Authors' contributions}

$\mathrm{ZZ}$ collected soil samples, isolated the fungal strains, assayed the fungal enzyme production, identified the fungal isolates, and was involved in drafting the manuscript. JLL and JYL purified and characterized the $\beta$-glucosidase TkBgl3A, cloned the encoding gene, and participated in drafting the manuscript. CJD participated in data analysis. QSM participated in conceiving and designing the study. JXF conceived, designed the study, and critically revised and finally approved the manuscript. All authors read and approved the final manuscript.

\section{Acknowledgements}

This work was supported by grants from the Guangxi Natural Science Foundation (grant number 2012GXNSFGA060005), the Bagui Scholar Program of Guangxi (grant number 2011A001), Guangxi Program for Science and Technology Development (grant number 11107008-5) and the National Natural Science Foundation of China (grant number 30960013).

Received: 25 April 2014 Accepted: 30 June 2014

Published: 17 July 2014

\section{References}

1. Malhi Y: Carbon in the atmosphere and terrestrial biosphere in the 21st century. Philos Trans A Math Phys Eng Sci 2002, 360:2925-2945.

2. Lynd LR, Weimer PJ, van Zyl WH, Pretorius IS: Microbial cellulose utilization: fundamentals and biotechnology. Microbiol Mol Biol Rev 2002, 66:506-577.

3. Boer W, Folman LB, Summerbell RC, Boddy L: Living in a fungal world: impact of fungi on soil bacterial niche development. FEMS Microbiol Rev 2005, 29:795-811.

4. Wilson DB: Microbial diversity of cellulose hydrolysis. Curr Opin Microbiol 2011, 14:259-263.

5. Weimer PJ, Russell JB, Muck RE: Lessons from the cow: what the ruminant animal can teach us about consolidated bioprocessing of cellulosic biomass. Bioresour Technol 2009, 100:5323-5331.

6. Distel DL, Beaudoin DJ, Morrill W: Coexistence of multiple proteobacterial endosymbionts in the gills of the wood-boring Bivalve Lyrodus pedicellatus (Bivalvia: Teredinidae). Appl Environ Microbiol 2002, 68:6292-6299 
7. Ohkuma M: Termite symbiotic systems: efficient bio-recycling of lignocellulose. Appl Microbiol Biotechnol 2003, 61:1-9.

8. Béguin P, Aubert JP: The biological degradation of cellulose. FEMS Microbiol Rev 1994, 13:25-58.

9. Gusakov AV: Alternatives to Trichoderma reesei in biofuel production. Trends Biotechnol 2011, 29:419-425.

10. Le Crom S, Schackwitz W, Pennacchio L, Magnuson JK, Culley DE, Collett JR, Martin J, Druzhinina IS, Mathis H, Monot F, Seiboth B, Cherry B, Rey M, Berka R, Kubicek CP, Baker SE, Margeot A: Tracking the roots of cellulase hyperproduction by the fungus Trichoderma reesei using massively parallel DNA sequencing. Proc Natl Acad Sci U S A 2009, 106:16151-16156.

11. Singhania RR, Patel AK, Sukumaran RK, Larroche C, Pandey A: Role and significance of beta-glucosidases in the hydrolysis of cellulose for bioethanol production. Bioresour Technol 2013, 127:500-507.

12. Hong J, Tamaki H, Kumagai $\mathrm{H}$ : Cloning and functional expression of thermostable $\beta$-glucosidase gene from Thermoascus aurantiacus. Appl Microbiol Biotechnol 2007, 73:1331-1339.

13. Cantarel BL, Coutinho PM, Rancurel C, Bernard T, Lombard V, Henrissat B: The Carbohydrate-Active EnZymes database (CAZy): an expert resource for glycogenomics. Nucleic Acids Res 2009, 37:D233-D238.

14. Yoon JJ, Kim KY, Cha CJ: Purification and characterization of thermostable $\beta$-glucosidases from the brown-rot basidiomycete Fomitopsis palustris grown on microcrystalline cellulose. J Microbio/ 2008, 46:51-55.

15. Liu W, Hong J, Bevan DR, Zhang YH: Fast identification of thermostable beta-glucosidase mutants on cellobiose by a novel combinatorial selection/screening approach. Biotechnol Bioeng 2009, 103:1087-1094.

16. Del Pozo MV, Fernández-Arrojo L, Gil-Martínez J, Montesinos A, Chernikova TN, Nechitaylo TY, Waliszek A, Tortajada M, Rojas A, Huws SA, Golyshina OV, Newbold CJ, Polaina J, Ferrer M, Golyshin PN: Microbial $\beta$-glucosidases from cow rumen metagenome enhance the saccharification of lignocellulose in combination with commercial cellulase cocktail. Biotechnol Biofuels 2012, 5:73

17. Liu D, Zhang R, Yang X, Zhang Z, Song S, Miao Y, Shen Q: Characterization of a thermostable $\beta$-glucosidase from Aspergillus fumigatus Z5, and its functional expression in Pichia pastoris X33. Microb Cell Fact 2012, 11:25.

18. Uchima CA, Tokuda G, Watanabe H, Kitamoto K, Arioka M: Heterologous expression and characterization of a glucose-stimulated $\beta$-glucosidase from the termite Neotermes koshunensis in Aspergillus oryzae. Appl Microbiol Biotechnol 2011, 89:1761-1771.

19. Feng Y, Duan CJ, Liu L, Tang JL, Feng JX: Properties of a metagenome-derived beta-glucosidase from the contents of rabbit cecum. Biosci Biotechnol Biochem 2009, 73:1470-1473.

20. Beloqui A, Nechitaylo TY, López-Cortés N, Ghazi A, Guazzaroni ME, Polaina J, Strittmatter AW, Reva O, Waliczek A, Yakimov MM, Golyshina OV, Ferrer M, Golyshin PN: Diversity of glycosyl hydrolases from cellulose-depleting communities enriched from casts of two earthworm species. Appl Environ Microbiol 2010, 76:5934-5946.

21. Nakajima M, Yamashita T, Takahashi M, Nakano Y, Takeda T: Identification, cloning, and characterization of $\beta$-glucosidase from Ustilago esculenta. Appl Microbiol Biotechnol 2012, 93:1989-1998.

22. Hong MR, Kim YS, Park CS, Lee JK, Kim YS, Oh DK: Characterization of a recombinant beta-glucosidase from the thermophilic bacterium Caldicellulosiruptor saccharolyticus. J Biosci Bioeng 2009, 108:36-40.

23. Merino ST, Cherry J: Progress and challenges in enzyme development for biomass utilization. Adv Biochem Eng Biotechnol 2007, 108:95-120.

24. Montenecourt BS, Eveleigh DE: Selective screening methods for the isolation of high yielding cellulase mutants of Trichoderma reesei. In Hydrolysis of Cellulose: Mechanisms of Enzymatic and Acid Catalysis, Advances in Chemistry Series, Volume 181. Edited by Brown R, Jurasek L. Washington, DC: American Chemical Society; 1979:289-301.

25. Marjamaa K, Toth K, Bromann PA, Szakacs G, Kruus K: Novel Penicillium cellulases for total hydrolysis of lignocellulosics. Enzyme Microb Technol 2013, 52:358-369.

26. Turon X, Rojas OJ, Deinhammer RS: Enzymatic kinetics of cellulose hydrolysis: a QCM-D study. Langmuir 2008, 24:3880-3887.

27. Ahola S, Turon X, Osterberg M, Laine J, Rojas OJ: Enzymatic hydrolysis of native cellulose nanofibrils and other cellulose model films: effect of surface structure. Langmuir 2008, 24:11592-11599.

28. Chang VS, Holtzapple MT: Fundamental factors affecting biomass enzymatic reactivity. Appl Biochem Biotechnol 2000, 84-86:5-37.
29. Zhang $Y H$, Lynd LR: Toward an aggregated understanding of enzymatic hydrolysis of cellulose: noncomplexed cellulase systems. Biotechnol Bioeng 2004, 88(7):797-824.

30. Desrochers M, Jurasek L, Paice MG: Production of cellulase, betaglucosidase, and xylanase by schizophyllum commune grown on a cellulose-peptone medium. Dev Ind Microbiol 1981, 22:675-684.

31. Li X, Gao P: Isolation and partial characterization of cellulose-degrading strain of Streptomyces sp. LX from soil. Lett Appl Microbiol 1996, 22:209-213.

32. Mountfort DO, Asher RA: Production and regulation of cellulase by two strains of the rumen anaerobic fungus Neocallimastix frontalis. Appl Environ Microbiol 1985, 49:1314-1322.

33. Tiwari $P$, Misra BN, Sangwan NS: $\beta$-Glucosidases from the fungus Trichoderma: an efficient cellulase machinery in biotechnological applications. Biomed Res In 2013, 2013:203735.

34. Kov́acs K, Megyeri L, Szakacsa G, Kubicekc CP, Galbeb M, Zacchi G: Trichoderma atroviride mutants with enhanced production of cellulase and $\beta$-glucosidase on pretreated willow. Enzyme Microb Technol 2008, 43:48-55.

35. Chandra M, Kalra A, Sharma PK, Sangwan RS: Cellulase production by six Trichoderma spp. fermented on medicinal plant processings. J Ind Microbiol Biotechnol 2009, 36:605-609.

36. Park AR, Hong JH, Kim JJ, Yoon JJ: Biochemical characterization of an extracellular $\beta$-glucosidase from the fungus, Penicillium italicum, isolated from rotten citrus peel. Mycobiology 2012, 40:173-180.

37. Chauve M, Mathis H, Huc D, Casanave D, Monot F, Lopes Ferreira N: Comparative kinetic analysis of two fungal beta-glucosidases. Biotechnol Biofuels 2010, 3:3.

38. Ramani G, Meera B, Vanitha C, Rao M, Gunasekaran P: Production, purification, and characterization of a $\beta$-glucosidase of Penicillium funiculosum NCL1. Appl Biochem Biotechnol 2012, 167:959-972.

39. Ohgren K, Bura R, Lesnicki, Saddler J, Zacchi G: A comparison between simultaneous saccharification and fermentation and separate hydrolysis and fermentation using steam-pretreated corn stover. Process Biochem 2007, 42:834-839.

40. Bhatia Y, Mishra S, Bisaria VS: Purification and characterization of recombinant Escherichia coli-expressed Pichia etchellsii beta-glucosidase II with high hydrolytic activity on sophorose. Appl Microbiol Biotechnol 2005, 66:527-535.

41. Chen $\mathrm{H}$, Hayn M, Esterbauer $\mathrm{H}$ : Purification and characterization of two extracellular beta-glucosidases from Trichoderma reesei. Biochim Biophys Acta 1992, 1121:54-60

42. Miller GL: Use of Dinitrosalicylic acid reagent for determination of reducing sugar. Anal Chem 1959, 31:426-428.

43. Ghose TK: Measurement of cellulase activities. Pure Appl Chem 1987, 59:257-268.

44. Berghem LE, Pettersson LG: The mechanism of enzymatic cellulose degradation. Isolation and some properties of a beta-glucosidase from Trichoderma viride. Eur J Biochem 1974, 46:295-305.

45. Parry NJ, Beever DE, Owen E, Vandenberghe I, Van Beeumen J, Bhat MK: Biochemical characterization and mechanism of action of a thermostable beta-glucosidase purified from Thermoascus aurantiacus. Biochem J 2001, 353:117-127.

46. Bradford MM: A rapid and sensitive method for the quantitation of microgram quantities of protein utilizing the principle of protein-dye binding. Anal Biochem 1976, 72:248-254.

47. Michlmayr H, Schümann C, da Silva NM, Kulbe KD, del Hierro AM: Isolation and basic characterization of a $\beta$-glucosidase from a strain of Lactobacillus brevis isolated from a malolactic starter culture. J Appl Microbiol 2010, 108:550-559.

48. Saghai-Maroof MA, Soliman KM, Jorgensen RA, Allard RW: Ribosomal DNA spacer-length polymorphisms in barley: mendelian inheritance, chromosomal location, and population dynamics. Proc Natl Acad Sci 1984, 81:8014-8018.

\section{doi:10.1186/1754-6834-7-107}

Cite this article as: Zhang et al:: Predominance of Trichoderma and Penicillium in cellulolytic aerobic filamentous fungi from subtropical and tropical forests in China, and their use in finding highly efficient $\beta$-glucosidase. Biotechnology for Biofuels 2014 7:107. 